\title{
SOCIALINIŲ TINKLŲ NAUDOJIMAS ŠVIETIME: TEORINĖS İŽVALGOS
}

\author{
Doc. dr. Dalia Prakapienė \\ Generolo Jono Žemaičio Lietuvos karo akademija
}

Doc. dr. Romas Prakapas

Mykolo Romerio universitetas

\begin{abstract}
Anotacija. Nuolatinè socialiniu tinklu plètra modernioje žiniu visuomenèje kelia naujus iššūkius ir suteikia naujas galimybes. Pastaruoju metu vis daugiau demesio skiriama socialiniu tinklų naudojimui švietime. Todèl šio straipsnio tikslas - pristatyti socialiniu tinklu naudojimo švietime (tiek formaliajame, tiek neformaliajame) galimybes. Straipsnis modeliuojamas remiantis kokybinio tyrimo metodologinemis nuostatomis. Jame pristatomo tyrimo pagrindiniai metodai - publikuotu tyrimo rezultaty metaanalize ir kokybine turinio analizè, leidusios atskleisti pagrindines socialiniu tinklu, naudojamu švietimo poreikiams, galimybes, taip pat kai kurias galimas grèsmes. Straipsnyje pristatomi 2017 m. rugpjūčio - spalio mèn. straipsnio autorių atlikto tyrimo rezultatai, kurie leidžia teigti, kad moksliniai tyrimai, susije su socialiniu tinkly naudojimu ugdymo procese, daugiausiai sutelkti i suaugusiuju švietimo nagrinejjima. Socialiniai tinklai leidžia studentams tapti aktyviais bendradarbiais, kurti žinias ir keisti savo socialine padètį, interaktyviomis priemonemis plečia ịtraukaus mokymosi galimybes. Socialiniai tinklai griauna tradicinio mokymo nustatytas aiškias ribas tarp profesinès ir socialinès erdvès ir verčia kitaip pažvelgti ị mokymo ir mokymosi procesus, remia ir palaiko interaktyvius tarpusavio santykius, komunikacija, bendruomenę ir bendradarbiavima, kuria edukacines erdves.
\end{abstract}

Pagrindiniai žodžiai: socialiniai tinklai, švietimas, suaugusiujų švietimas.

\section{Ivadas}

Šiuolaikinėje modernioje žinių visuomenėje plètojantis technologijoms, kuriantis naujoms medijoms atsirado daugiau galimybių ne tik keistis informacija, bendrauti ir bendradarbiauti nepaisant valstybių sienų, rasių ir tautybių ypatumų, bet ir panaudoti jas ịvairiose žmogaus veiklos srityse. Pastaruoju metu šis itin dažnai mokslinèje spaudoje (pvz., Al-Rahmi, Othman, Yusuf, 2015; Pečiulis, 2016; Dabija, Babut, Dinu, Lugojan, 2017 ir kt.) aptariamas reiškinys būdingas beveik visoms socialinio gyvenimo sritims. Jau ịprasta tapo tirti tiek pačius socialinius tinklus, tiek jų taikymo versle galimybes (pvz., Vilkaitè-Vaitonè, 2015; Trakimavičiūtè, 2017 
ir pan.). Vis dažniau pagrindiniu analizės objektu (pvz., Levickaitè, 2010) pasirenkamas skirtingų kartų sąveikos ir komunikacijos aspektas. Su tuo siejamos idẻjos socialinius tinklus plačiau naudoti tiek formaliojo, tiek neformaliojo mokymo procese (pvz., Šliogerienè, Masoodi, Gulbinskienè, 2016), kartu, savaime suprantama, analizuojant galimas grèsmes (pvz., Žibènienè, Brasienè, 2013). Taigi, švietimas yra viena tų sričių, kuriose moderniujų̨ technologijų intensyvus kūrimas ir diegimas, socialinių tinklų integravimas tampa neatskiriama ugdymo proceso dalimi.

Analizuojant naujujjų technologijų ir medijų skverbtị matyti, kad Lietuvos situacija nėra išskirtinè. Jau nemažai publikuota Lietuvos mokslininkų tyrimų (pvz., Gudonienė ir kt., 2013; Dudaitė, Prakapas, 2017), pristatančių socialinių tinklų naudojimo Lietuvoje bendrą situaciją ar šio reiškinio tendencijas. Tyrimai rodo, kad socialiniai tinklai ir naujosios (kuriamos ir adaptuojamos) technologijos sudaro palankias sąlygas arba sukuria tokias prielaidas pedagogams, siekiantiems ugdomuju tikslų. Savaime suprantama, negalima atmesti ir mokslininkų pastebėtų grèsmių ir pavojų (Cain, Fink, 2010; Hosterman 2012 ir kt.).

Nors mokslinèje spaudoje plačiai aprašoma socialinių tinklų įtaka visuomenei ir ịvairioms gyvenimo sritims, vis dažniau teikiamos ịvairios socialinių tinklų panaudojimo švietime galimybiu analizès ir interpretacijos, atliekami fragmentuoti, pavieniai tyrimai, tačiau šiek tiek stokojama bendro holistinio požiūrio ị aptariamą reiškini iš edukologinès perspektyvos. Lietuviškajame diskurse tai tampa itin aktualu ir dèl adekvataus dėmesio stokos šiam reiškiniui nacionaliniuose strateginiuose švietimo dokumentuose. Pavyzdžiui, Valstybineje švietimo 2013-2022 metu strategijoje (2014) tik netiesiogiai įvardyti orientyrai, kuriais vadovaujantis galima „apčiuopti“ nagrinėjamą reiškinį. Atsižvelgiant ị nurodytas aplinkybes straipsnyje nagrinèjama mokslinė problema suformuluota klausimu - kokios yra teorinès socialinių tinklų panaudojimo švietime galimybès?

Straipsnio tikslas - pristatyti socialinių tinklų panaudojimo švietime galimybes.

Straipsnio objektas - socialinių tinklų naudojimas švietime.

Tyrimo metodai. Straipsnis modeliuojamas remiantis kokybinio tyrimo metodologinèmis nuostatomis (Creswell, 2009), leidžiančiomis geriau pažinti nagrinèjamą reiškini (Suter, 2012) ir išskirti jo ryškiausias problemines sritis. Straipsnyje pristatomo tyrimo pagrindiniai metodai - publikuotų tyrimų rezultatų metaanalizė (Konstantopoulos, 2008) ir kokybinè turinio analizé (Flick, 2014), leidusios atskleisti pagrindines socialinių tinklų panaudojimo švietimo poreikiams galimybes ir kai kurias galimas grèsmes.

Straipsnyje pristatomi $2017 \mathrm{~m}$. rugpjūčio - spalio mèn. straipsnio autorių atlikto tyrimo rezultatai. Atliekant tyrimą tarptautinèse mokslinių publikacijų duomenų bazėse, turinčiose atviros prieigos galimybes, buvo ieškoma tam tikrus kriterijus atitinkančiu publikacijų. Publikacijų atrankai buvo taikomi keli kriterijai: 1) publikacijos turèjo būti naujos (ne senesnès nei 5 metų, kelios ị analizę įtrauktos publikacijos yra senesnès nei 5 metų, bet ne senesnès nei 10 metų dèl atitikties 
antrajam analizès kriterijui), 2) publikacijos turèjo būti paskelbtos skirtinguose pasaulio mokslo leidiniuose, publikuojamuose skirtinguose regionuose (Europoje, JAV, Azijoje, Australijoje), 3) publikacijos turèjo būti parašytos anglų kalba. Atliekant kokybinę turinio analizę pagal publikacijų turinị buvo suformuluotos pagrindinès analizès temos (interaktyvus bendravimas, pedagoginis įrankis, itraukusis mokymas(is), informacijos sklaida, bendradarbiavimas, informacijos publikavimas, kritinis mąstymas, socializacija, reprezentacija).

\section{Socialinių tinklų švietime analizių raiška}

Socialiniais tinklais žmonès dažniausiai naudojasi dèl kelių priežasčių. Pirmiausia tai komunikacijos, bendravimo su kitais priemonè. Tai paaiškinama poreikiu priklausyti tam tikroms grupėms, noru jaustis reikalingam, reikšmingam. Socialiniai tinklai padeda patenkinti šias reikmes, nes, prisijungdami prie įvairių grupių, žmonès neretai patenkina savo kitus socialinius poreikius. Antra, socialiniai tinklai labai dažnai naudojami informacijos paieškai, susipažinimui su ịvairiomis nuomonėmis, vertinimais; socialiniai tinklai tampa erdve, kur dažnai ieškoma informacijos apie ịvairius įvykius, naujienas, renginius ir pan. Galiausiai svarbu pažymèti ir tai, kad socialiniai tinklai tampa svarbiais socializacijos proceso skatintojais. Tyrejai pastebi, kad gana anonimiška erdvė tampa puikia galimybe dalyvauti asmeniniuose pokalbiuose ir viešose diskusijose, išvengiant tiesioginio kontakto, bendravimo akis ị akị (face to face) su pašnekovu. Čia svarbu, kad, pasak Janiūnienès (2007, p. 62), socialiniai tinklai sugriauna sienas ir bendravimui atstumas nebeturi jokios reikšmès, „socialinis tinklas konstruoja kontekstą ir situaciją ir, atvirkščiai, socialinis tinklas yra konstruojamas pagal kontekstą ir situaciją“, o kuo tinklas platesnis ir kuo kokybiškesni jo kūrèjų santykiai, tuo paprastai efektyviau jis naudojamas. Be to, socialinis tinklas igalina ryšius megzti ne tik tam tikroje šalyje, bet ir visame pasaulyje - čia negalioja nei laiko, nei erdvès suvaržymai, kaip pažymi Prakapienė ir Prakapas (2016); tokị tinklą, kuris paplitęs globaliu mastu, o patys jo kūrejjai yra ịvairių pasaulio šalių, tautybių, rasių ir kt. atstovai, galima vadinti tarptautiniu.

Mokslinejje spaudoje socialiniai tinklai ir jų vaidmuo švietime vertinamas labai nevienareikšmiškai. Atliekantys šiuos tyrimus mokslininkai sukūrė ne vieną klasifikatorių. Pavyzdžiui, Kajanova (2014) savo tyrime akcentuoja tam tikras socialinių tinklų galimybes: galimybę dalyvauti ịvairiose veiklos srityse komentuojant, diskutuojant (taip sugriaunamos sienos tarp teikiančiųjų ir gaunančiujjų informaciją), atvirumą (socialiniai tinklai yra atviri ir leidžia aktyviai dalyvauti komentuojant, vertinant, teikiant papildomą informaciją), galimybę bendrauti (dalyvauti pokalbiuose - čia svarbu abipusis dialogas), galimybę greitai kurti bendruomenes, bendraminčių (socialines) grupes ir efektyviai bendrauti, plèsti ryšius (socialiniai tinklai klesti dèl sąsajų su kitais tinklais ir socialinėmis medijomis, ištekliais ir žmonèmis).

Kiek anksčiau grupė mokslininkų (Kietzman ir kt., 2011) išskyrẻ septynis 
socialinių tinklų funkcinius blokus, tokius kaip identiteto palaikymas (asmeninès informacijos teikimas); pokalbių (komunikacijos procesas socialiniuose tinkluose); dalijimasis (vaizdinès ir tekstinès informacijos teikimas); dalyvavimas (dalyviu statuso tinkluose atskleidimas); ryšiai (vartotojų tarpusavio ryšiai); reputacija; priklausymas grupėms. Šio tyrimo metu taikant atvirajį kodavimą buvo išskirti kiti kriterijai (žr. 1 lentelę).

1 lentelè. Socialiniai tinklai švietime (sudaryta autorių)

\begin{tabular}{|c|c|c|c|c|c|c|c|c|c|}
\hline Autoriai & 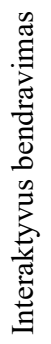 & 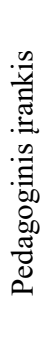 & 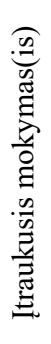 & 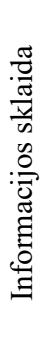 & 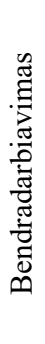 & 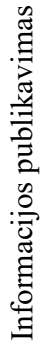 & 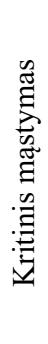 & 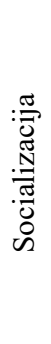 & 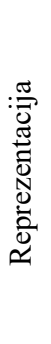 \\
\hline Ajjan, Hartshorne (2008) & * & & & & & & $*$ & & \\
\hline Grreenhow ir kt. (2009) & & * & & & & & & & \\
\hline Mazman, Usluel, (2010) & $*$ & & & $*$ & $*$ & & & & \\
\hline McLoughlin, Lee (2010) & $*$ & & $*$ & & & & & & \\
\hline Tadros (2011) & & & & & $*$ & & $*$ & * & \\
\hline DiVall, Kirwin (2012) & $*$ & & & & $*$ & & & * & \\
\hline Tariq ir kt. (2012) & * & & $*$ & * & $*$ & $*$ & & $*$ & \\
\hline Lumby, Anderson, Hugman (2014) & * & & $*$ & $*$ & $*$ & $*$ & & & \\
\hline Mao (2014) & $*$ & & $*$ & $*$ & $*$ & * & & & \\
\hline Greenhow, Lewin (2016) & $*$ & & & $*$ & $*$ & $*$ & & & \\
\hline Prakapas, Prakapienė (2016) & $*$ & & & $*$ & & $*$ & & $*$ & \\
\hline Sobaih ir kt.(2016) & & $*$ & & $*$ & $*$ & $*$ & & & \\
\hline Peruta, Shields (2017) & & & & & & & & & $*$ \\
\hline Vimala (2017) & $*$ & $*$ & & & $*$ & & & & \\
\hline
\end{tabular}

Kai kurie autoriai, aptardami socialinius tinklus, jų svarbą, panaudojimo švietime būdus, išskiria nemažai pozityvių aspektų ir taikymo galimybių. Tai dažniausia siejama su interaktyvumo galimybėmis. McLoughlin, Lee (2010) pabréžia socialinių tinklų pedagoginių galimybių pasirinkimo principus. Minètas autorius teigia, kad veikla socialiniuose tinkluose gali būti interaktyvus besimokančiųų bendravimas, per kurị pats mokymasis įgaus virtualų nuolatinị palaikymą. Akivaizdu, jog tokia sąveika, kuri skatina mokymąsi ir suvokiama kaip aktyvus procesas, yra itin vertinga mokymuisi, kritinio mąstymo ugdymui ir sąmoningam įsitraukimui ị ugdymo procesą. Panašios pozicijos laikosi ir Mao (2014), kuris, analizuodamas so- 
cialinius tinklus, išskiria komunikaciją, dalijimąsi informacija, bendradarbiavimą, informacijos pateikimą ir interaktyvumą.

Greenhow ir Lewin (2016) teigia, kad tipinès socialinès medijos leidžia individualiems vartotojams per profilio puslapius dalytis informacija, i ją reaguoti, reikšti emocijas, rašyti atsiliepimus, nuomones, rekomendacijas. İvairios informacijos skelbimas, dalijimasis ja, „tag 'inimas“ (i publikuojamą medžiagą kitų asmenų itraukimas) socialiniuose tinkluose leidžia labai greitai keistis žiniomis. Tai, akivaizdu, yra susiję su greičiu, kuriuo pasižymi didžiulis ir nuolat besikeičiantis informacijos srautas (socialiniai tinklai, „blog 'ai“, medijos sklaidos priemonès, dalijimosi informacija ịrankiai, bibliografiniai vadybos įrankiai ir pan.).

Nemažai tyrèjų atkreipia demesi i formaluji bendravimą ir bendradarbiavimą. Pavyzdžiui, kai kurie (Mazman ir Usluel, 2010), nagrinėdami socialinių tinklų reiškini, akcentuoja interaktyvią veiklą ir bendravimą, bendradarbiavimą, dalijimąsi informacija socialiniuose tinkluose. Minètiems autoriams pritaria ir kiti (Ajjan, Hartshorne, 2008), pabrèžiantys taip pat vieną esminių socialinių tinklų savybių įtraukuji dalyvavimą, kuris, remiantis jų atlikto tyrimo duomenimis, sukuria kritinio mąstymo ugdymo prielaidas.

Atliekant tyrimą pastebèta tam tikra tendencija - socialiniai tinklai sietini su asmenų priklausomumu tam tikroms grupėms. Pavyzdžiui, DiVall ir Kirwin (2012) išskiria ịdomų socialinių tinklų vaidmenį - socializaciją. Socialiniai tinklai šioms asmenų grupèms padeda siekti socialinių tikslų socializuojantis; priklausymas tam tikroms grupėms padeda ne tik spręsti kai kurias su amžiumi susijusias socialines problemas, bet ir susieti interaktyvuji komunikavimą su konkrečiu mokymusi (kryptinga komunikacija susijusi su mokymosi turiniu ir pasiekimais). Tai, remiantis tyrimų rezultatais, dažniausiai susiję su Facebook'o galimybėmis. Towner ir Munoz (2011) tyrimų duomenys rodo, kad Facebook'as dažniausiai naudojamas aukštujų mokyklų studijų procese. Socialiniai tinklai padeda sukurti bendradarbiavimo edukacinę aplinką - studentai juose gali bendrauti, kurti grupes, diskutuoti, bendrai daryti darbus ir pan. Šias ịžvalgas patvirtina Sturgeon ir Walker (2009), teigdami, kad, kuriant edukacines erdves, svarbus ir dėstytojo, ir studentų bendravimas socialiniuose tinkluose. Kai kurių tyrèjų atliktų tyrimų duomenys leidžia daryti prielaidas, kad socialiniai tinklai (pvz., Facebook) sukuria artimesnę ir patogesnę bendravimo ir bendradarbiavimo aplinką, kuri koreliuoja su geresne mokymosi aplinka. Pavyzdžiui, Mendez ir kt. (2009) tyrimai parodè, kad studentai, tarp kurių Facebook'o draugų yra dėstytojų, turi aukštesnius savęs vertinimo kriterijus, nei tie, kurie tokių ryšių nepalaiko. Vis tik pažymètina, kad ne visi dėstytojai turi ar nori turèti paskyras socialiniuose tinkluose, nepaisydami, kad, anot Madge ir kt. (2009), Facebook'as padeda socializuotis ir integruotis ị universiteto aplinką. Kartu Towner ir Munoz (2011) teigia, kad nereikia sureikšminti „draugystės“ socialiniuose tinkluose. Tai ne tas pats, kas realiame gyvenime. Tai - socialiniai santykiai, kuriems palaikyti nuolat kuriamos naujos taisyklès ir sudaromi nauji susitarimai.

Socialiniai tinklai palaipsniui tampa mokymosi priemone, tačiau jokiu būdu 
ne tikslu. Nepaisant Tadros (2011) tyrimų, kurie rodo, kad socialiniai tinklai sukuria erdvę kritiniam mąstymui ugdyti, kūrybiškumui skatinti, bendradarbiauti su ịvairiomis socialinėmis ar bendraamžių grupèmis, bendrauti su pedagogais, be išskirtu privalumų, jie turi nemažai trūkumų. Visų pirma, kaip minètas autorius nurodo, kyla sunkumų užtikrinant tinkamą ugdymo procesą, ypač siekiant jo kokybės ir ji valdyti.

Dar vienas aspektas, kuris išryškèja atliekant turinio analizę, - socialinių tinklų naudojimas siekiant reklamuoti ir reprezentuoti konkrečią ugdymo ịstaigą. Peruta ir Shields (2017) ịrodè, kad socialiniai tinklai yra ypač svarbūs studentams ị aukštąsias mokyklas pritraukti. Išanalizavus $66 \mathrm{JAV}$ geriausių kolegijų ir universitetu Facebook'o paskyras ir dalyvių ịsitraukimo ì pateikiamos informacijos komentavimą rezultatus, nustatyta, kad kuo socialinių tinklų vadybininkai sugeba patraukliau, įtaigiau ir kokybiškiau pateikti konkrečią aktualią informaciją (turini)), tuo daugiau pritraukiama diskusijų dalyvių, savo ruožtu ženkliai išauga komentuojančiujų ar diskusijose dalyvaujančiujų skaičius. Tai, akivaizdu, svarbiausia studentų pritraukimo į aukštąsias mokyklas etape.

Kiek anksčiau panašią problemą tyrè ir Lietuvos mokslininkai. ZailskaitėJakštė ir Kuvykaitė (2012) nagrinėjo komunikacijos socialinėje žiniasklaidoje igyvendinimo populiarinant aukštujjų mokyklų studijas klausimus. Šių autorių tyrimas atskleide, kad Lietuvos valstybinès universitetinès aukštosios mokyklos stebi vienos kitų komunikaciją socialinėje žiniasklaidoje ir dažniausiai naudoja tuos pačius jos kanalus - Facebook ir YouTube. Labiausiai būsimuosius studentus patraukia vizualiai pateikta informacija, kuri yra nauja, skirta tikslinei auditorijai, kurios negalima rasti kituose interneto puslapiuose, t. y. itin daug dèmesio skiriama žinutės turiniui: neigiamas žinutes universitetai siekia paversti pozityvia informacija, necenzūrines - šalina. Vis dèlto minètos autorès nurodo, kad kol kas Lietuvos universitetinès aukštosios mokyklos nepakankamai išnaudoja egzistuojančius socialinės žiniasklaidos būdus monitoringui atlikti.

Panašiu laikotarpiu kaip ir Lietuvoje Tariq (2012) su kolegomis analizavo socialinių tinklų situaciją ir nustaté, kad tuo metu socialiniai tinklai ugdymui buvo naudojami atliekant namų darbų užduotis ar konsultuojantis su draugais. Tačiau svarbu tai, kad šalia pozityvių apraiškų buvo užfiksuota ne viena grèsmè - nors socialinių tinklų sukuriama virtuali erdvè leidžia besimokantiesiems atviriau bendrauti, ypač bijantiems viešai kalbėti, daug jų socialiniuose tinkluose prisistato suklastotomis tapatybėmis, t. y. užsiregistravę netikrais vardais. Didžioji šioje situacijoje problema ta, kad sukuriamos prielaidos pažeisti etikos normas ar autorių teises, eskaluoti konfliktines situacijas ir pan.

Analizuojant socialinių tinklų panaudojimo švietime galimybes svarbus yra Chakraborty (2015) tyrimas. Šiame tyrime atlikus socialinių tinklų naudojimo edukaciniame procese duomenų analizę paaiškejjo, jog jaunimas dabar daug laiko iššvaisto socialiniuose tinkluose, nors turètų jo daugiau skirti mokymuisi. Tyrimo autorius išanalizavo socialinių tinklų privalumus ir grésmes mokymuisi (žr. 2 lentelę). 
Akivaizdu, tam, kad sumažintume neigiamą socialinių tinklų poveikị, būtina mokytis saugiai jais naudotis. Vienareikšmiškai svarbu tai, kad socialiniai tinklai yra gera vieta pasidalinti asmeninėmis (dažniausiai sèkmès) istorijomis, naujausiomis žiniomis, bendradarbiauti ir kt. Socialiniai tinklai leidžia bendrauti žmonèms tiesiogiai: geografinès sienos tarsi ištrinamos ir bendravimo procesas vyksta palyginti pigiai (interneto ryšio paslaugos nebrangios, komunikavimui skirtų įrenginių kainos taip pat labai ịvairios). Informacija ne tik dalijamasi, bet ir - svarbu - atsiranda greitas grįžtamasis ryšys. Informacijos srautas labai didelis ir dinamiškas. Kita vertus, dèl informacijos gausos, trumpam pasitraukus iš šio srauto, lengva pasiklysti, pasimesti. Be to, socialiniuose tinkluose labai daug netikrų vartotojų, virtualūs tinklai neapsaugo nuo galimo sukčiavimo ir nusikalstamų veikų ar net nusikaltimų.

2 lentelè. Socialinių tinklų privalumai ir grèsmès (pagal Chakraborty, 2015)

\begin{tabular}{|c|c|}
\hline Privalumai & Grèsmès \\
\hline 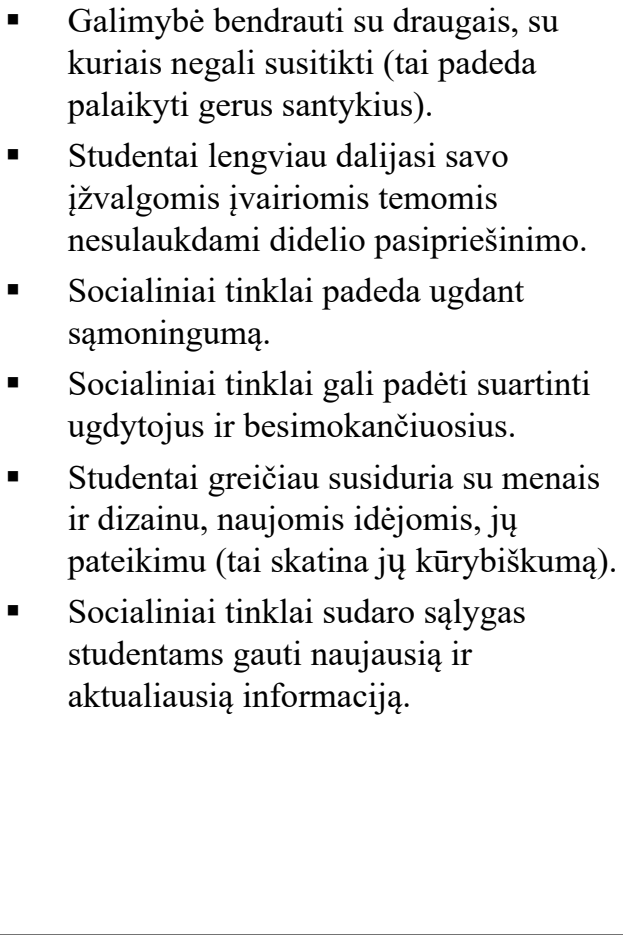 & $\begin{array}{l}\text { - Sumažėęs dėmesys detalėms: kalbos } \\
\text { taisyklingumui, naudojami trumpiniai } \\
\text { ir pan. } \\
\text { - } \\
\text { Studentai tampa priklausomi nuo } \\
\text { socialinių tinklų, užuot bendravę su } \\
\text { šeima ir susitikę su draugais. } \\
\text { - Socialiniuose tinkluose pateikiama per } \\
\text { daug asmeninès informacijos, kuri gali } \\
\text { būti panaudota netinkamai. } \\
\text { - Studentai, kurie daugiau laiko } \\
\text { praleidžia socialiniuose tinkluose, } \\
\text { sunkiau prisitaiko realiame gyvenime ir } \\
\text { bendrauja ,gyvai“. } \\
\text { Per didelis įsitraukimas ị socialinius } \\
\text { tinklus turi neigiamą poveikị studentų } \\
\text { rezultatams. } \\
\text { Studentai naršo naktimis, o tai } \\
\text { neigiamai veikia jų fizinę ir psichinę } \\
\text { sveikatą. } \\
\text { Socialiniuose tinkluose didesnė erdvė } \\
\text { patyčioms. }\end{array}$ \\
\hline
\end{tabular}

Pastaruoju metu publikuoti Vimalos (2017) tyrimo, skirto studentų nuomonei apie socialinių tinklų panaudojimo mokymuisi aukštojoje mokykloje galimybes išsiaiškinti, rezultatai parodè, kad yra šeši pagrindiniai veiksniai, kurie turi poveiki studentų norui mokytis naudojantis socialiniais tinklais: savarankiškumas, informacinès technologijos, kolektyviškumas, poreikis bendrauti, daryti ịtaką ir veiklos rezultatai. Statistinè duomenų analizè parodè, kad informacinès technologijos ir ko- 
lektyviškumo poveikis yra statistiškai nereikšmingi. Didžiausią poveikį mokymuisi socialiniuose tinkluose daro savarankiškumas. Vis dèlto bendros išvados rodo, kad nors studentų ketinimai ir norai yra dideli, praktiškai mokymuisi socialiniai tinklai naudojami minimaliai. Studentai juose dažniausiai ieško mokomosios medžiagos, tačiau edukologai ir vadybininkai turètų pasinaudoti studentų entuziazmu ir skatinti specialių programų, kuriose socialiniai tinklai taptų mokymo ir mokymosi dalimi, kūrimą. Sobaih ir kt. (2016), nagrinedami socialinių tinklų panaudojimo aukštosios mokyklos ugdymo procese galimybes, pritaria nuomonei, kad tai - didelị potencialą turintis mokymo ir mokymosi įrankis, tačiau šiuo metu naudojamas minimaliai.

Panašūs Mansa ir Ranieri (2016) tyrimų rezultatai. Analizuojant socialinių tinklų naudojimo aukštajame moksle ypatumus nustatyta, kad socialiniai tinklai galinga mokymo ir mokymosi praktikos pokyčių varomoji jèga, nes yra atviri, interaktyvūs ir socialūs (skatinantys bendrauti). Tyrimo rezultatai parodè, kad socialiniai tinklai naudojami ugdymo procese vis dar labai ribotai ir aukštųjų mokyklų pedagogai nèra linkę jų integruoti ị ši procesą dèl kelių priežasčių: kultūrinio pasipriešinimo, pedagoginių ir institucinių apribojimų. Vis dèlto svarbu ịsiklausyti ị Gomez ir kt. (2012) argumentus, jog, nepaisant to, kad studentai apskritai socialinius tinklus naudoja labai intensyviai, jie retai tai daro akademiniais tikslais. Kai kurie studentai vis tiek socialinius tinklus pirmiausia mato kaip savo privačią erdvę, todèl jos, anot Hosterman (2012), nèra linkę naudoti edukaciniams tikslams. Šalia šių grèsmių yra problemų, susijusių su teise. Cain ir Fink (2010) atkreipia dèmesi i tai, kad socialiniuose tinkluose dažnai platinami ịvairiausi vaizdai, tekstai ir kt. Todèl tiek dèstytojams, tiek studentams svarbu nepažeisti autorių teisių, paisyti su jomis susijusių reikalavimų, išmanyti pagrindinius teisès ir etikos principus.

Apibendrinant galima pasiremti Al-Rahmi ir kt. (2015), taip pat Marcial (2016) tyrimų išvadomis, kurios rodo, kad socialinių tinklų naudojimo mastas keičia požiūrị i mokymą(si), kai pedagogas leidžia besimokantiesiems kurti ar integruoti naujus socialinius tinklus. Tai padeda ugdyti tyrejų kartą. İ socialinius tinklus nèra žiūrima kaip ị tam tikrą mokymo strategiją, bet tai puiki priemoné, padedanti paįvairinti tradicinị mokymąsi. Mokymosi aplinka tampa analitinè ir konstruktyvi, o veikla lieka autentiška, sklandi ir lanksti.

\section{Išvados}

1. Moksliniai tyrimai, susiję su socialinių tinklų naudojimu ugdymo procese, daugiausia nukreipti ị suaugusiųų švietimo klausimų nagrinèjimą, pavyzdžiui, kaip socialiniai tinklai naudojami aukštosiose mokyklose ir kolegijose. Socialiniai tinklai leidžia studentams tapti aktyviais bendradarbiais, kurti žinias, suteikia galimybę keisti savo socialinę padètị. Socialiniai tinklai nèra tapatūs tradicinèms mokymo priemonèms.

2. Pastaruoju metu socialinių tinklų, kaip pedagoginio instrumento, vaidmuo vis labiau auga. Socialinių tinklų interaktyviosios galimybės kuria ịtraukaus mo- 
kymosi galimybes. Tai savo ruožtu remia ir palaiko interaktyvius tarpusavio santykius, komunikaciją, bendruomeniškumą ir bendradarbiavimą, kuria edukacines erdves.

3. Būtina adekvačiai suvokti socialinių tinklų, kaip edukacinių erdvių, galimas edukacines ir socialines grèsmes, kurios mokslininkų apibrèžiamos kaip laiko švaistymas, per didelis informacijos kiekis, sudètingesnis edukacinio proceso valdymas, netinkamas ir neefektyvus veiklų koordinavimas.

4. Socialiniai tinklai verčia kitaip pažvelgti ị šiuolaikines mokymo ir mokymosi galimybes. Tai iš dalies naujas, sparčiai besiplètojantis procesas, kuriam ịvaldyti reikia ne tik tam tikrų kompetencijų, bet ir atsakomybès (etinès, teisinès), adekvataus suvokimo. Socialiniai tinklai griauna aiškias tradicinio mokymo tarp profesinès ir socialinès erdvès nubrèžtas ribas, taip pat ribas tarp viešumo ir privatumo.

\section{Literatūra}

1. Ajjan, H., Hartshorne, R. (2008). Investigating Faculty Decisions to Adopt Web 2.0 Technologies: Theory and Empirical Tests. Internet and Higher Education, 11 (2), 71-80.

2. Al-Rahmi, W. M., Othman, M. S., \& Yusuf, L. M. (2015). The role of social media for collaborative learning to improve academic performance of students and researchers in Malaysian Higher Education. International Review of Research in Open and Distributed Learning, 16(4), 177-204.

3. Cain J., \& Fink J. (2010) Legal and ethical issues regarding social media and pharmaceutical education. American Juornal of Pharmacy Education, 74(10), p. 184.

4. Chakraborty, S. K. (2015). Impact of social media/ social networks on education and life of undergraduate level students of karimganj town-a survey sudipta deb roy. International Research Journal of Interdisciplinary \& Multidisciplinary Studies (IRJIMS), 11 (1), 141-147.

5. Creswell, J. W. (2009). Research design: qualitative, quantitative, and mixed methods approaches. Thousand Oaks (Calif.) ; London: SAGE Publications.

6. Dabija, D.-C., Babut, R., Dinu, V., \& Lugojan, M. I. (2017). CrossGenerational Analysis of Information Searching Based on Social Media in Romania. Transformation in Business \& Economics, 16(2), 248-270.

7. DiVall, M. V., \& Kirwin, J. L. (2012). Using Fcebook to facilitate courserelated discussions between students and faculty members. American Juornal of Pharaceutical Education, 76 (2), 1-5.

8. Dudaite, J., \& Prakapas, R. (2017). The Experience of Teachers in the Application of ActivInspire Interactive Evaluation System in Classroom: A Case of Teachers in Lithuania. Informatics in Education, 16(2), 181-195.

9. Flick, U. (2014). The SAGE handbook of qualitative data analysis. London: SAGE Publications Ltd. 
10. Gómez, M., Roses, S., \& Farias, P. (2012). The academic use of social networks among university students. Comunicar: Scientific Journal of Media Education, 19 (38), 131-138.

11. Greenhow, C., \& Lewin, C. (2016). Social media and education: reconceptualizing the boundaries of formal and informal learning. Learning. Media and Technology, 41 (1), 6-30.

12. Greenhow, C., Robelia, B., \& Hughes, J. E. (2009). Learning, teaching, and scholarship in a digital age. Educational Researcher, 38 (4), 246-59.

13. Gudonienè, D., Rutkauskienè, D., Lauraitis, A. (2013). Pažangių mokymosi technologijų naudojimas ugdymo procese. Informacijos mokslai, 66, p. $96-107$.

14. Hosterman, A. R. (2012) Tweeting 101: twitter and college classroom. In H.S.N. Al-Deen and J.A.Hendricks (eds.) Social media: Usage and impact (pp. 93-100). Lexington Books, UK.

15. Janiūnienè, E. (2008). Vadybininko informacinè elgsena organizacijoje: socialinių tinklų naudojimas. Informacijos mokslai, 40, 57-65.

16. Kajanová, H. (2014). The use of social media in system of education in Slovakia. International Multidisciplinary Scientific Conference on Social Sciences \& Arts SGEM. (pp. 1011-1018).

17. Kietzman, J. H., Hermkens, K., McCarthy, I. P., \& Silvestre, B. S. (2011) Social media? Get serious! Understanding the functional building blocks of social media. Business Horizons, 24, 241-251.

18. Konstantopoulos, S. (2008). An introduction to meta-analysis. In Osborne, J. Best practices in quantitative methods (pp. 177-194). Thousand Oaks, CA: SAGE Publications Ltd.

19. Levickaite, R. (2010). Generations X, Y, Z: How Social Networks Form the Concept of the World Without Borders (the Case of Lithuania). Limes, 3(2), $170-183$.

20. Lumby C., Anderson N, Hugman S. (2014). Apres Le Deluge: social media in learning and teaching. The Journal of International Communicatio, 20 (2), p. 119-132.

21. Madge, C., Meek, J., Wellens, J., \& Hooley, T. (2009). Facebook, social integration and informal learning at university: 'It is more for socialising and talking to friends about work than for actually doing work. Learning, Media and Technology, 34 (2), 141-155.

22. Mansa, S., \& Ranieri, M. (2016). Facebook and the others. Potentials and obstacles of social media for teaching in higher education. Computer \& Education, 95, 216-230.

23. Mao, J. (2014) Social media for learning: a mixed methods study of high school students. Technology affordances and perspectives. Computers in Human Behavior, 33, 213-223.

24. Marcial A. K. T. (2016). Descriptors of social media use in higher 
education. ASEAN Journal of Open Distance Learning, 8 (2), 12-23.

25. Mazman, S.G., Usluel, Y.K. (2010). Modeling educatioal usage of Facebook. Computers \&Education, 55 (2): 444-453.

26. McLoughlin, C., \& Lee, M. J. W. (2010). Personalised and self regulated learning in the web 2.0 era: International exemplars of innovative pedagogy using social software. Australasian Journal of Educational Technology, 26 (1), p. 28-34.

27. Mendez, J. P., Curry, J., Mwavita, M., Kennedy, K., Weinland, K., \& Bainbridge, K. (2009). To friend or not to friend: Academic interaction on Facebook. International Journal of Instructional Technology \& Distance Learning, 6 (9), 33-47.

28. Pečiulis, Ž. (2016). Digital era: from mass media towards a mass of media. Filosofija. Sociologija, 27(3), 240-248.

29. Peruta, A., \& Shields, A. B. (2016). Social media in higher education: understanding how colleges and universities use Facebook. Journal of Marketing for Higher Education, 1-13.

30. Prakapienè, D., \& Prakapas, R. (2016). The impact of social media on intercultural communication. Organizacja społeczna $w$ strukturach sieci. Doświadczenia i perspektywy rozwoju w Europie Środkowej i Wschodniej (p. 165173). Lublin: Wydawnictwo KUL.

31. Sobaih, A. E. E., Moustafa, M. A., Ghandforoush, P. \& Khan, M. (2016) To use or not to use? Social media in higher education in developing countries. Computers in Human Behavior, 58, 296-305.

32. Sturgeon, C. M., \& Walker, C. (2009). Faculty on Facebook: Confirm or deny? Presented at the 14th Annual Instructional Technology Conference. Murfreesboro, Tennessee.

33. Suter, W. N. (2012). Introduction to educational research: A critical thinking approach. Thousand Oaks, CA: SAGE Publications Ltd.

34. Šliogerienė, J., Masoodi, M., \& Gulbinskienė, D. (2016). Facebook as a Tool in University English Language Education. Acta paedagogica Vilnensia, 36, 34-41.

35. Tadros, M. (2011). A social media approach to higher education. Educating Educators with Social Media. By: Wankel, Charles. Series: Cutting-edge Technologies in Higher Education, Vol. 1. Edition: 1st ed. Bingley, UK : Emerald Group Publishing Limited.

36. Tariqs ,W. et.al. (2012). The Impact of Social Media Social Networks on Education Students of Pakistan. IJCSI International Journal of Computer Science, $9(4)$.

37. Towner, L., \& Munoz, C. L. (2011). Facebook and education: a classroom connection? Educating Educators with Social Media. By: Wankel, Charles. Series: Cutting-edge Technologies in Higher Education, Vol. 1. Bingley, UK : Emerald Group Publishing Limited.

38. Trakimavičiūtè, G. (2017). Ryšių su klientais palaikymas pasitelkiant socialinị tinklą „Facebook“. Informacijos mokslai, 77, 145-159. 
39. Valstybinè švietimo 2013-2022 metu strategija. (2014). Vilnius: Švietimo aprūpinimo centras.

40. Vilkaitè-Vaitonè, N. (2015). Komunikacija su tiksline auditorija per socialinius tinklus: apgyvendinimo ịstaigu atvejis. Management Theory \& Studies for Rural Business \& Infrastructure Development, 37(4), 586-597.

41. Vimala, B. (2017). Key determinants for intention to use social media for learning in higher education institutions. Universal Access in the Information Society, 16 (2), 289-301.

42. Zailskaite-Jakste, L., \& Kuvykaite, R. (2012) Implementation of Communication in Social Media by Promoting Studies at Higher Education Institutions. Engineering Economics, 23 (2), 174-188.

43. Žibėnienè, G., \& Brasienè, D. (2013). Naudojimasis internetu, internetiniais socialiniais tinklais ir galimai patiriamos grèsmès: mokinių nuomonè. Socialines technologijos, 3(1), 53-67. 


\title{
THE USE OF SOCIAL MEDIA IN EDUCATION: THEORETICAL INSIGHTS
}

\author{
Assoc. Prof. Dr. Dalia Prakapienè \\ General Jonas Žemaitis Military Academy of Lithuania
}

Assoc. Prof. Dr. Romas Prakapas

Mykolas Romeris University

\section{Summary}

New challenges and opportunities emerge as social media sites are more and more widely used in the modern-day knowledge society. Scientists worldwide, including Lithuania, analyse the use of social media in the processes of communication, cooperation, socialisation, information sharing, etc. The focus, however, has recently been shifting towards adapting and using social networking sites in education. Thus, the aim of this article is to present the opportunities for the use of social media sites in education. The article applies the methodological principles of qualitative research. The main methods of the research presented in the article - meta-analysis of the findings of published research studies and qualitative content analysis - helped to identify the main opportunities for the use of social media for educational purposes, as well as some possible threats. The article presents the results of the research carried out from August to September 2017. The findings suggest that the main focus of scientific research into the use of social networking sites in the process of education is on the analysis of adult education. Social media facilitate students' active cooperation in the network, thus creating knowledge, and allowing for a change in the students' social status. Social networking sites are not identical with traditional educational tools. The role of social media as a pedagogical tool is increasing. Social networking sites create opportunities for engaged learning through interactive features, which in turn facilitates interactive relationships, communication, community, and cooperation, and creates educational spaces. Social media create a necessity to rethink the processes of teaching and learning. This is a relatively new and developing process that requires, apart from having certain competences, accepting and adequately understanding responsibility (ethical, legal). Social networking sites are removing the boundaries between professional and social space that are clear in traditional education. They are destroying the line between public and private.

Keywords: social media, social networking sites, education, adult education. 


\section{AUTORIŲ LYDRAŠTIS}

Autoriaus vardas, pavardė: Dalia Prakapienè

Mokslo laipsnis ir vardas: socialinių mokslų daktarè, docentė

Darbo vieta ir pareigos: Generolo Jono Žemaičio Lietuvos karo akademijos Vadybos katedros docente

Autoriaus mokslinių interesų sritys: švietimo inovacijos, personalo vadyba, lyderio ugdymo strategijos

Telefonas ir el. paštas: +370 5210 3557, dalia.prakapiene@1ka.1t

Autoriaus vardas, pavardė: Romas Prakapas

Mokslo laipsnis ir vardas: socialinių mokslų daktaras, docentas

Darbo vieta ir pareigos: Mykolo Romerio universiteto Edukologijos ir socialinio darbo instituto docentas

Autoriaus mokslinių interesų sritys: tyrimų metodologija, edukacinès technologijos, pedagoginès kompetencijos

Telefonas ir el. paštas: +370 5271 4710,prakapas@mruni.eu

\section{AUTHORS' COVER LETTERS}

Author's name and surname: Dalia Prakapienè

Academic degree and name: Doctor of Social Sciences, Associate Professor

Workplace and position: General Jonas Žemaitis Military Academy of Lithuania, Department of Management

Author's research interests: educational innovation, human resource management, leadership development

Telephone and e-mail address: +370 5210 3557, dalia.prakapiene@lka.lt

Author's name and surname: Romas Prakapas

Academic degree and name: Doctor of Social Sciences, Associate Professor

Workplace and position: Mykolas Romeris University, Institute of Educational Sciences and Social Work

Author's research interests: research methodology, educational technology, pedagogical competences

Telephone and e-mail address: +370 5271 4710,prakapas@mruni.eu 